\title{
ANALISIS KESALAHAN PENGGUNAAN KALIMAT PASIF (UKEMIBUN) DALAM TES BUNPOU MAHASISWA TAHUN MASUK 2017 PROGRAM STUDI PENDIDIKAN BAHASA JEPANG UNIVERSITAS NEGERI PADANG
}

\author{
Lhutfiah Nur Putri ${ }^{1}$, Hendri Zalman ${ }^{2}$ \\ Prodi Pendidikan Bahasa Jepang, FBS, UNP ${ }^{1}$ \\ Prodi Pendidikan Bahasa Jepang, FBS, UNP2 \\ Email Penulis : lhutfiah.np@gmail.com
}

\begin{tabular}{lr}
\hline Sejarah Artikel \\
\hline Submit $: 2019-07-30$ \\
Diterima $: 2019-08-19$ \\
Diterbitkan : 2019-12-15
\end{tabular}

\section{Kata Kunci:}

Error Analysis, Passive Sentence (Ukemibun).

\section{Abstract}

This study discusses the keigo ability of sixth semester students in the year of 2016 Japanese Language Education Study Program, Padang State University. The purpose of this study was to determine the ability of keigo (sonkeigo and kenjougo) VI semester students in the year of 2016 2016 Japanese Language Education Study Program, Padang State University. The type of research used in this study is quantitative research with descriptive methods. The population in this study was the sixth semester students of the year of entry in 2016, the Japanese Language Education Study Program, Padang State University, amounting to 30 people. The sample in this study was the sixth semester students of the year of entry in 2016, the Japanese Language Education Study Program, Padang State University, amounting to 30 people. The data in this study are scores of students' sixth semester keigo ability test results in 2016 Japanese_Language Education Study Program, Padang State University. Based on the results of the research conducted it can be concluded that the ability of keigo in general is in the "sufficient" qualification with an average of 55.8. While the sonkeigo ability is in the "more than enough" qualification with an average of 63.6 and kenjougo's ability in qualifications "less" with an average of 45.7 .

\footnotetext{
${ }^{1}$ Mahasiswa Prodi Pendidikan Bahasa Jepang FBS UNP Iulus pada tanggal.......

2 Dosen Prodi Pendidikan Bahasa Jepang FBS UNP
} 


\section{PENDAHULUAN}

Bahasa merupakan alat komunikasi dalam kehidupan bersosialisasi. Pada era globalisasi, kebutuhan terhadap kemampuan berbahasa sangat tinggi, terutama berbahasa asing. Ada banyak pembelajaran bahasa asing di Indonesia, salah satunya bahasa Jepang. Setiap bahasa memiliki keunikan dan karakteristik tersendiri yang membuat bahasa tersebut berbeda dari yang lainnya, misalnya bahasa Jepang. Dilihat dari segi kebahasaannya, karakteristik bahasa Jepang ada pada huruf yang digunakan, kosakata dan pola atau struktur bahasanya.

Perbedaan struktur gramatika bahasa Jepang dan bahasa Indonesia menurut Sutedi (2011:41) menjadi salah satu kendala bagi pembelajar bahasa Jepang. Kalimat verbal (transitif) dalam bahasa Jepang secara umum berpola SOP (subjekobjek-predikat) dan frase nominanya menggunakan hukum MD (menerangkanditerangkan), berbeda dengan bahasa Indonesia yang berpola SPO (subjekpredikat-objek) dengan hukum DM (diterangkan-menerangkan).

Dalam bahasa Jepang terdapat macam-macam bentuk kalimat, salah satunya adalah kalimat pasif. Menurut Sutedi (2014:79), kalimat pasif dalam bahasa Jepang disebut ukemi atau judoubun. Kalimat pasif bahasa Jepang memiliki keistimewaan tersendiri jika dibandingkan dengan bahasa lain. Misalnya, bisa dibentuk dari verba transitif dan bisa juga dari verba intransitif.

Dalam bahasa Indonesia pembentukan kata kerja pasif adalah dengan membubuhi awalan di pada kata dasar dari kata kerja tersebut, dan dalam kalimat adakalanya ditambah dengan partikel oleh. Tetapi pembentukan kata kerja pasif dalam bahasa Jepang adalah mula-mula kata kerja tersebut dibuat dalam wujud konjugasi $\mathbf{V}_{1}$. Kemudian, wujud konjugasi $\mathbf{V}_{\mathbf{1}}$ tersebut dibubuhi dengan akhiran rareru pada kelompok kata kerja ichidan doushi dan kata kerja kuru, dan reru pada kelompok kata kerja godan doushi dan kata kerja suru (Alim, 2014:85).

Sutedi (2014:79-80) menyatakan bahwa dilihat dari segi makna, kalimat pasif bahasa Jepang dibagi dua macam, yaitu pasif netral (chuuritsu ukemi) dan pasif adversatif (meiwaku ukemi). Dari segi struktur, kalimat pasif bahasa Jepang terdiri dari pasif langsung (chokusetsu ukemi) dan pasif tidak langsung (kansetsu ukemi). Kalimat pasif langsung yaitu kalimat pasif yang dibentuk dari kalimat transitif yang objeknya berupa manusia atau benda yang bernyawa saja. Kalimat pasif tak langsung yaitu kalimat pasif yang dibentuk dari kalimat transitif yang objeknya benda mati (di dalamnya mencakup bagian tubuh, banda yang dimiliki); atau kalimat pasif yang dibentuk dari kalimat intransitif.

Menurut Sutedi (2015:7), kalimat pasif bahasa Jepang merupakan materi yang cukup sulit bagi pembelajar bahasa Jepang di Indonesia, karena banyak perbedaannya dengan kalimat pasif dalam bahasa Indonesia. Perbedaan ini dapat dianggap sebagai suatu keunikan sehingga menjadi ciri dari kalimat pasif bahasa Jepang. Beberapa hal yang dapat dianggap sebagai keunikan dalam kalimat pasif bahasa Jepang antara lain sebagai berikut.

1. Dilihat dari konstruksinya ada sebutan pasif langsung (chokusetsu ukemi) dan pasif tidak langsung (kansetsu ukemi).

2. Dilihat dari segi maknanya ada pasif bermakna netral (chuuritsu no ukemi) dan ada pasif yang bermakna adversatif (meiwaku no ukemi).

3. Verba yang digunakan untuk mengisi predikatnya selain verba transitif 
(tadoushi) dan ditransitif (nijuu tadoushi), dapat juga diisi oleh verba intransitif (jidoushi).

4. Nomina pengisi subjek selain berasal dari fungsi objek (objek langsung) dapat juga berasal dari fungsi pelengkap (objek tidak langsung) dalam kalimat aktifnya, bahkan dapat berasal dari luar kalimat aktifnya.

5. Nomina tidak bernyawa tidak dapat digunakan secara bebas untuk mengisi subjek kalimat pasif, tetapi ada beberapa ketentuan yang mengikatnya.

6. Penggunaan kalimat pasif dalam bahasa Jepang tidak seproduktif penggunaan kalimat pasif bahasa Indonesia, sehingga hal ini sering menjadi penyebab munculnya kesalahan (goyou) dan penggunaan kalimat pasif yang berlebihan (tayou) pada pembelajar bahasa Jepang di Indonesia. Keunikan kalimat pasif dalam bahasa Jepang ini berpotensi memunculkan masalah, seperti terjadinya kesalahan berbahasa pada pembelajar yang pada umumnya terjadi karena adanya transfer negatif bahasa ibu dengan bahasa Jepang. Kesalahan yang muncul bisa berupa penggunaan kosakata, penggunaan pola kalimat dan sebagainya (Sutedi, 2014:1). Contohnya.

1. この本は私に読まれている。

Kono hon wa watashi ni

yomareteiru. Buku ini sudah saya

baca.

2. 私のラブレターは母に読まれている。

Watashi no raburetaa wa haha ni

yomareteiru. Surat cinta saya dibaca oleh ibu.

3. この水は飲まれてもいい。

Kono mizu wa nomaretemo

ii. Air ini boleh diminum

4. 私は山本先生に日本語を教えられた。

Watashi wa Yamamoto sensei ni nihongo wo oshierareta.

Saya diajari bahasa Jepang oleh Pak Yamamoto.

(Sutedi, 2015:4-5)

Menurut Sutedi (2015:4-5) kesalahan pada contoh (1) sampai (3) muncul akibat pengaruh dari bahasa Indonesia, seperti yang tampak dalam terjemahan bahasa Indonesianya. Kesalahannya adalah subjek pada ketiga contoh di atas diisi oleh nomina tidak bernyawa, pelaku pada contoh (1) diisi oleh orang pertama, dan bentuk pasif pada contoh (3) disertai unsur modalitas. Hal seperti ini tidak ada dalam pemasifan bahasa Jepang.

Berbeda dengan contoh (4) yang dilihat dari konstruksi kalimat ini berterima, tetapi makna dan nuansa yang disampaikannya tidak tepat. Pak Yamamoto sebagai penutur bahasa Jepang akan merasa tidak nyaman atau mungkin tersinggung begitu mendengar kalimat tersebut karena, bagi si penutur para siswa terpaksa atau mungkin menderita dengan diajarkannya bahasa Jepang oleh Pak Yamamoto. Akan tetapi, sebaliknya bagi pembelajar orang Indonesia yang mengucapkannya justru akan menganggap bahwa kalimat tersebut lebih sopan dan terkandung rasa terima kasih.

Contoh kesalahan lain penggunaan kalimat pasif dalam penelitian terdahulu yang dilakukan oleh Ernawati (2011:13) adalah sebagai berikut. 
1. おととい、先生は山田さんをほめられた。

Ototoi,sensei wa yamada san wo homerareta.

Dua hari yang lalu, Yamada dipuji oleh guru.

2. 私のケーキは妹に食べられました。

Watashi no keeki wa imouto ni taberaremashita.

Kue saya dimakan oleh adik.

Kesalahan pada contoh nomor (1) adalah letak posisi subjek dan pelaku yang tertukar dan partikel yang digunakan untuk pelaku harusnya ni. Kesalahan pada contoh nomor (2) adalah struktur kalimat tidak sesuai dengan pembentukkan kalimat pasif bahasa Jepang. Kesalahan seperti ini terjadi karena ada hubungannya dengan pengaruh dari bahasa ibu (bahasa Indonesia).

Berdasarkan permasalahan di atas, untuk melihat kesalahan penggunaan kalimat pasif secara lebih detail perlu dilakukan penelitian. Dalam hal ini peneliti mengangkat judul penelitian: "Analisis Kesalahan Penggunaan Kalimat Pasif (Ukemibun) Dalam Tes Bahasa Jepang Mahasiswa Tahun Masuk 2017 Prodi Pendidikan Bahasa Jepang Universitas Negeri Padang”. Mahasiswa tahun masuk 2017 dipilih karena mahasiswa tersebut telah mempelajari kalimat pasif pada semester genap (Januari-Juni) tahun 2019.

\section{METODE PENELITIAN}

Jenis penelitian ini adalah penelitian deskriptif dengan analisis data kualitatif. Menurut Sutedi (2011:20,58) penelitian deskriptif adalah penelitian yang bertujuan untuk memberikan (menjabarkan) suatu keadaan atau fenomena yang ada secara apa adanya. Penelitian deskriptif ini dilakukan untuk menggambarkan, menjabarkan suatu fenomena yang terjadi saat ini dengan menggunakan prosedur ilmiah untuk menjawab masalah secara aktual. Sedangkan analisis data kualitatif menurut Widiyoko (dalam Oktaviani, 2018:29) adalah data yang menunjukkan kualitas atau mutu sesuatu yang ada, baik keadaan, proses, peristiwa atau kejadian lainnya yang dinyatakan dalam bentuk pernyataan atau berupa kata-kata. Analisis data kualitatif dilakukan untuk mengetahui hasil kesalahan siswa berupa penjelasan melalui kata-kata. Data dari penelitian ini adalah analisis kesalahan kalimat pasif dengan sumber data berupa tes bahasa Jepang pada mahasiswa tahun masuk 2017 Prodi Pendidikan Bahasa Jepang Universitas Negeri Padang.

Instrumen dalam penelitian ini adalah soal objektif berbentuk pilihan ganda dan isian untuk mencari kesalahan penggunaan kalimat pasif. Instrumen penelitian adalah alat yang digunakan oleh peneliti untuk memperoleh data. Instrumen yang digunakan dalam penelitian ini adalah tes. Tes merupakan alat ukur yang biasanya digunakan untuk mengukur hasil belajar siswa setelah selesai satu satuan program pengajaran tertentu (Sutedi, 2011: 156-157).

Adapun teknik pengumpulan data sebagai berikut. Pertama, memberikan tes kepada mahasiswa sebanyak satu kali. Kedua, setelah selesai lembar kerja di kumpul. Ketiga, setelah data terkumpul, selanjutnya adalah memeriksa instrumen 
tersebut diperiksa berdasarkan indikator yang diteliti kemudian memberikan skor atau penilaian hasil tes yang telah dikerjakan. Kemudian dilanjutkan dengan menganalisis data dengan langkah sebagai berikut. Pertama, mengklasifikasikan data sesuai jenis, bentuk dan penyebab kesalahan Kedua, data dianalisis dengan menggunakan rumus untuk mencari hasil persentase kesalahan. Ketiga, setelah mendapatkan persentase dari kesalahan responden, kemudian dilanjutkan dengan membahas hasil analisis dengan cara deskriptif. Keempat, menyimpulkan hasil pembahasan.

\section{HASIL DAN PEMBAHASAN Temuan Penelitian}

Berdasarkan analisis terhadap hasil tes kesalahan dari penggunaan kalimat pasif mahasiswa tahun masuk 2017 Program Studi Pendidikan Bahasa Jepang Universitas Negeri Padang pada tes bunроu dianalisis data berupa bentuk kesalahan yaitu morfologi dan sintaksis, jenis kesalahan yaitu lapses dan mistake, lalu penyebab kesalahan yaitu interferensi bahasa ibu, faktor performansi, faktor kompetensi, dan faktor generalisasi.

\section{a. Bentuk Kesalahan}

Terdapat banyak bentuk kesalahan dalam penelitian yang dilakukan pada mahasiswa tahun masuk 2017 dalam penggunaan kalimat pasif. Bentuk kesalahan dalam penelitian ini adalah morfologi dan sintaksis. Berikut adalah tabel jumlah kesalahan yang terdapat dalam tes bunpou mahasiswa.

Tabel 1. Bentuk Kesalahan Penggunaan Kalimat Pasif

\begin{tabular}{|c|c|c|}
\hline Bentuk Kesalahan & Jumlah Kesalahan & Persentase \\
\hline Morfologi & 240 & $43 \%$ \\
\hline Sintaksis & 315 & $57 \%$ \\
\hline
\end{tabular}

Berdasarkan tabel di atas, dapat dilihat jumlah kesalahan pada bagian kesalahan morfologi adalah 240 kesalahan dengan persentase 43\%. Kemudian pada bentuk kesalahan sintaksis terdapat jumlah kesalahan sebanyak 315 dengan persentase $57 \%$. Artinya, dalam penelitian ini dengan tes bunpou sebagai sumber data, bentuk kesalahan yang paling tinggi terjadi adalah kesalahan sintaksis.

\section{b. Jenis Kesalahan}

Jenis kesalahan yang diteliti dalam penelitian ini adalah lapses dan mistake. Berikut adalah tabel jumlah kesalahan yang terdapat dalam tes bunpou mahasiswa.

Tabel 2. Jenis Kesalahan Penggunaan Kalimat

Pasif

\begin{tabular}{|c|c|c|}
\hline Jenis Kesalahan & Jumlah Kesalahan & Persentase \\
\hline Lapses & 50 & $53 \%$ \\
\hline
\end{tabular}




\section{Mistake}

44

$47 \%$

Berdasarkan tabel di atas, dapat dilihat jumlah kesalahan pada bagian kesalahan lapses adalah 50 kesalahan dengan persentase 53\%. Kemudian pada jenis kesalahan mistake terdapat jumlah kesalahan sebanyak 44 dengan persentase 47\%. Artinya, dalam penelitian ini dengan tes bunpou sebagai sumber data, bentuk kesalahan yang paling tinggi terjadi adalah kesalahan lapses.

\section{c. Penyebab Kesalahan}

Dalam penelitian ini, penyebab kesalahan yang diteliti adalah penyebab interferensi bahasa ibu, faktor performansi, faktor kompetensi dan faktor generalisasi. Berikut adalah tabel jumlah kesalahan yang terdapat dalam tes bunpou mahasiswa.

Tabel 3. Penyebab Kesalahan Penggunaan Kalimat

Pasif

\begin{tabular}{|c|c|c|}
\hline Peneybab Kesalahan & Jumlah Kesalahan & Persentase \\
\hline Interferensi Bahasa Ibu & 64 & $7 \%$ \\
\hline Faktor Performansi & 44 & $5 \%$ \\
\hline Faktor Kompetensi & 515 & $56 \%$ \\
\hline Faktor Generalisasi & 292 & $32 \%$ \\
\hline
\end{tabular}

Berdasarkan tabel di atas, dapat dilihat jumlah kesalahan pada bagian kesalahan interferensi bahasa ibu adalah 64 kesalahan dengan persentase $7 \%$. Kemudian pada bagian faktor performansi terdapat jumlah kesalahan sebanyak 44 dengan persentase 5\%. Pada faktor kompetensi terdapat jumlah kesalahan sebanyak 515 dengan persentase $56 \%$. Dan pada bagian faktor generalisasi terdapat kesalahan sebanyak 292 dengan persentase 32\%. Artinya, dalam penelitian ini dengan tes bunpou sebagai sumber data, penyebab kesalahan yang paling tinggi terjadi adalah faktor kompetensi.

\section{Pembahasan}

Pada bagian ini akan diuraikan tiga hal mengenai hasil dari deskripsi data analisis kesalahan penggunaan kalimat pasif dalam tes bunpou mahasiswa tahun masuk 2017 Program Studi Pendidikan Bahasa Jepang Universitas Negeri Padang, yaitu sebagai berikut.

Pertama, bentuk kesalahan penggunaan kalimat pasif yang ditemukan dalam penelitian ini adalah bentuk kesalahan morfologi dan sintaksis dalam tes bunpou mahasiswa tahun masuk 2017 Program Studi Pendidikan Bahasa Jepang Universitas Negeri Padang. Berdasarkan hasil penelitian, pada deskripsi data dapat dilihat bahwa bentuk kesalahan yang paling tinggi terjadi adalah bentuk kesalahan sintaksis dengan jumlah kesalahan sebanyak 315 dan persentase sebesar 57\%. Sebagaimana Sutedi (2014:64) mengatakan bahwa kesalahan sintaksis merupakan cabang linguistik yang mengkaji tentang struktur kalimat dan unsur-unsur pembentukannya. Hal ini menyebabkan bentuk kesalahan sintaksis 
dalam penggunaan kalimat pasif banyak terjadi karena mahasiswa belum memahami penggunaan kalimat pasif secara keseluruhan baik dalam aspek penggunaan partikel, penggunaan kata kerja dan menerjemahkan.

Dalam penelitian relevan yang dilakukan oleh Novikasari dengan judul "Kesalahan Penggunaan Kalimat Pasif Bahasa Jepang Pada Mahasiswa Sastra Jepang Universitas Diponegoro" dan penelitian oleh Hidayah yang berjudul "Analisis Kesalahan Penggunaan Ukemi, Shieki, dan Shieki Ukemi Dalam Kalimat Bahasa Jepang", menunjukan hasil yang sama yaitu kesalahan yang paling tinggi terjadi terdapat pada kesalahan dalam penggunaan partikel, menentukan objek dan subjek, kesalahan dalam menerjemah. Artinya, kesalahan yang terjadi yaitu kesalahan dalam pembentukan kalimat pasif dalam aspek bentuk kesalahan sintaksis.

Kedua, jenis kesalahan penggunaan kalimat pasif dalam tes bunpou mahasiswa tahun masuk 2017 Program Studi Pendidikan Bahasa Jepang Universitas Negeri Padang yang ditemukan dalam penelitian ini adalah jenis kesalahan lapses dan mistake. Berdasarkan hasil penelitian, pada deskripsi data dapat dilihat bahwa jenis kesalahan yang paling tinggi terjadi adalah jeniskesalahan lapses dengan jumlah kesalahan sebanyak 50 dan persentase sebesar 53\%. Sebagaimana Corder (dalam Putri, 2018:20) mengatakan bahwa kesalahan lapses merupakan penyimpangan bentuk lahir karena beralihnya pusat perhatian topik pembicaraan secara sesaat. Kesalahan ini terjadi akibat ketidaksengajaan dan tidak disadari oleh penuturnya. Hal ini menyebabkan jenis kesalahan lapses dalam penggunaan kalimat pasif banyak terjadi karena mahasiswa bisa disebabkan oleh kelelahan tubuh atau terburu-buru dalam mengerjakan tes sehingga kesalahan dalam penulisan (slip of the pen). Dalam penelitian sebelumnya yang relevan dengan penlitian ini, tidak dibahas mengenai jenis kesalahan dalam penggunaan kalimat pasif. Sehingga hasil dalam penelitian ini tidak ditemukan relevansinya dengan penelitian sebelumnya.

Ketiga, penyebab kesalahan penggunaan kalimat pasif dalam tes bunpou mahasiswa tahun masuk 2017 Program Studi Pendidikan Bahasa Jepang Universitas Negeri Padang yang terdapat dalam penelitian ini adalah penyebab kesalahan yang disebabkan oleh interferensi bahasa ibu, faktor performansi, faktor kompetensi dan faktor generalisasi. Berdasarkan hasil penelitian, pada deskripsi data dapat dilihat bahwa penyebab kesalahan yang paling tinggi terjadi disebabkan oleh faktor kompetensi dengan jumlah kesalahan sebanyak 515 dan persentase sebesar $56 \%$.

Faktor kompetensi adalah kesalahan berbahasa yang disebabkan karena kurangnya pemahaman atau pengetahuan mengenai aturan dalam berbahasa. Hal ini menyebabkan banyak terjadinya kesalahan karena mahasiswa masih belum memahami aturan struktur pembentukan kalimat pasif bahasa Jepang dengan baik yang dapat dikategorikan cukup sulit. Penggunaan partikel dan menentukan subjek yang menjadi pelaku dan objek yang dikenai perbuatan sering membuat mahasiswa kebingungan dan menyebabkan terjadinya kesalahan. Penyebab kesalahan ini juga bisa disebabkan oleh faktor dari bahasa ibu yang memengaruhi saat menerjemahkan kalimat pasif bahasa Indonesia ke dalam bentuk kalimat pasif bahasa Jepang. 
Dalam penelitian sebelumnya, yang dilakukan oleh Novikasari dengan judul "Kesalahan Penggunaan Kalimat Pasif Bahasa Jepang Pada Mahasiswa Sastra Jepang Universitas Diponegoro" dan penelitian oleh Hidayah yang berjudul "Analisis Kesalahan Penggunaan Ukemi, Shieki, dan Shieki Ukemi Dalam Kalimat Bahasa Jepang", menyimpulkan bahwa kesalahan penggunaan kalimat pasif bahasa Jepang dipengaruhi oleh bahasa ibu. Kesalahan ini banyak terdapat pada bagian soal terjemahan yang artinya mahasiswa dipengaruhi oleh bahasa ibu yang menyebabkannya masih kebingungan dalam memahami kalimat.

\section{KESIMPULAN}

Berdasarkan hasil analisis data penelitian yang telah dilakukan, dapat disimpulkan hal berikut

1. Bentuk kesalahan yang paling tinggi dilakukan oleh mahasiswa tahun masuk 2017 Program Studi Pendidikan Bahasa Jepang adalah bentuk kesalahan sintaksis dengan persentase $57 \%$.

2. Jenis kesalahan yang paling tinggi dilakukan oleh mahasiswa tahun masuk 2017 Program Studi Pendidikan Bahasa Jepang adalah jenis kesalahan lapses dengan persentase $53 \%$.

3. Penyebab kesalahan yang paling tinggi terjadi pada mahasiswa tahun masuk 2017 Program Studi Pendidikan Bahasa Jepang adalah penyebab kesalahan faktor kompetensi dengan persentase $56 \%$.

4. Kemudian, diharapkan pengajar memberikan lebih banyak soal latihan. Selanjutnya, pengajar memperhatikan kemampuan mahasiswa dalam penggunaan kalimat pasif dan memberikan metode pengajaran yang mudah dipahami oleh mahasiswa dengan menggunakan media yang menarik sehingga mahasiswa dapat memahami materi tentang kalimat pasif bahasa Jepang yang cukup sulit.

\section{REFERENSI}

Zalman, H., Yani, D.,. (2018). Kemampuan Siswa Kelas X UPW SMK Nusatama Padang Dalam Menggunakan Shijisi. Omiyage: Jurnal Bahasa Dan

Pembelajaran Bahasa Jepang, 13(1), 26-34. Retrieved from

http://omiyage.ppj.unp.ac.id/index.php/omiyage/article/viewFile/81/13

Ardi, H., Muhd. Al Hafizh, \& Arianto, M. A. (Eds.). (2020). Kurnia dalam Bahasa: Pengkajian Bahasa, Sastra, Budaya \& Pengajarannya. Yogyakarta: Erhaka Utama.

Azoua, M. H. (2020). Language clubs and pedagogical approach to teach English: University of Parakou English club case. Lingua Didaktika: Jurnal Bahasa Dan Pembelajaran Bahasa, 14(1), 44-54. Retrieved from https://doi.org/10.24036/ld.v14i1.107995

Becerra, T., Herazo, J., Garcia, P., Sagre, A., \& Diaz, L. (2020). Using reading to learn for EFL students' reading of explanations. ELT Journal, 74(3), 237-246. Retrieved from https://doi.org/10.1093/elt/ccz053 
Handayani, T., Rozimela, Y., \& Fatimah, S. (2020). An analysis of English-speaking anxiety experienced by the second year students of English Language and Literarture Department of Universitas Negeri Padang and its causal factors. Journal of English Language Teaching, 9(3), 580-592.

Hapsari, B. S., \& Ena, O. T. (2019). English Pre-service Teachers' Identity during Teaching Practice: Narrative Research. International Journal of Indonesian Education and Teaching, 3(2), 204-214.

Kusumaningputri, R., \& Widodo, H. P. (2018). Promoting Indonesian university students' critical intercultural awareness in tertiary EAL classrooms: The use of digital photograph-mediated intercultural tasks. System, 72, 49-61. Retrieved 1 February 2018 from https://doi.org/10.1016/J.SYSTEM.2017.10.003

Mahmudah, R., \& Ardi, H. (2020). The use of instagram platform toward junior high school students' speaking ability. In Advances in Social Science, Education and Humanities Research (Vol. 411, pp. 364-369). Paris: Atlantis Press. Retrieved from https://doi.org/10.2991/assehr.k.200306.061

Putri, N. E., \& Sari, S. Y. (2020). Applying vlog assignment to develop students' speaking ability. In Advances in Social Science, Education and Humanities Research (Vol. 411, pp. 280-283). Retrieved from https://doi.org/10.2991/assehr.k.200306.046

Ristimäki, H. L., Tiitinen, S., Juvonen-Posti, P., \& Ruusuvuori, J. (2020). Collaborative decision-making in return-to-work negotiations. Journal of Pragmatics, 170, 189-205. Retrieved from https://doi.org/10.1016/j.pragma.2020.08.012

Sugiyono. (2017). Metode Penelitian Pendidikan Pendekatan Kuantitatif, Kualitatif,dan $R$ \& D. Bandung: Alfabeta.

Triastuti, A. (2020). Assessing English pre-service teachers' knowledge base of teaching: Linking knowledge and self-portrayal. TEFLIN Journal, 31(1), 108138. 